DOI 10.31392/NPU-nc.series15.2021.6(137).03

Grishko L.

senior lecturer at the Department of Physical Education

Zavadska $N$.

teacher of the department of physical education

Novikova I.

teacher of the department of physical education

National Technical University of Ukraine Igor Sikorsky Kyiv Polytechnic Institute

\title{
INFLUENCE OF PHYSICAL EXERCISES ON THE DEVELOPMENT OF MORPHOFUNCTIONAL INDICES OF STUDENT YOUTH
}

The article reveals the influence of physical exercises on the development of morpho-functional indicators of student youth. It was found that in students who regularly exercise, physical development indicators are within normal limits. In addition, exercise improves the psychological state of those who engage, increases motivation for physical education, improves well-being.

The modern focus on the creative assimilation of physical culture by the future specialist requires an orderly system of effectiveness on his intellectual, emotional, volitional and practical activities. This allows us to talk about physical education as an important way of forming a personality, citizen and future specialist, purposeful pedagogical process of involving student youth in the values of national physical culture. The purpose of physical education in higher education - the formation of physical culture of personality, creation conditions for general and professional training of students and increase on this basis of intellectual, creative and cultural wealth of the state. Achieving this goal involves the formation of the necessary motivational core of physical education and self-education, systematic physical culture and sports activities and development of physical abilities.

It is known that movements are the final expression of almost all processes occurring in the body. Unmet need for muscle activity has negative consequences for the functional state of the body and physical performance. Systematic physical exercises for a long period of time naturally lead to specific changes in the physical development of students. At the same time, the data of physical development studies become especially important when they are associated with indicators of the functional state of the organism, its efficiency and preparedness institutions.

Key words: physical education, physical exercises, morpho-functional indices, health, students of higher education

Гришко Л., Завадська Н., Новікова І. Вплив фізичних вправ на розвиток морфофункціональних показників студентської молоді. В статті розкрито вплив фізичних вправ на розвиток морфо ффункиіональних показників студентської молоді. Виявлено, що у студентів, які регулярно займаються фізичними вправами показники фрізичного розвитку знаходяться в межах норми. Встановлено, що тільки достатня рухова активність і певний режим праці та життя в поєднанні з іншими засобами запобігають зниженню продуктивності праці. Крім того заняття ффізичними вправами покращують психологічний стан тих, хто займається, підвищують мотивацію до занять з фізичного виховання, покращують самопочуття.

Ключові слова: фізичне виховання, фрізичні вправи, морфро функціональні індекси, здоров'я, студенти закладів вищої освіти, рухова активність.

Formulation of the problem. With the development of civilization, due to the reduction in the lives of people in the role of hard physical labor, the importance and place of physical culture is constantly growing. In essence, physical culture is the main (if not the only) means that guarantees the salvation of mankind from physical degradation and degeneration. After all, the impoverishment of a person's motor arsenal leads to a deterioration of his health, decline in creative activity, etc. Only sufficient motor activity and a certain mode of work and life in combination with other means prevent a decrease in productivity. No wonder physical culture is given much attention in many highly profitable companies in Western Europe, the United States and especially Japan. For employees here create excellent conditions for physical culture and sports. And workers who do not get sick, do not smoke, lead a healthy lifestyle and play sports, enjoy significant benefits: additional leave, personal allowances, a guarantee of work in retirement, and so on.

Formed in the process of development of human society, physical culture clearly marked the relationship between preparation for work and its results. The complexity of the content of human activity each time increases the requirements for the level of physical and mental fitness, as, for example, in the training of astronauts, pilots, submariners and representatives of other modern professions. The functions of physical culture are also manifested in the constant accumulation and transfer of experience, the creation of new methods and means of influencing the psycho-physical state of people. This experience is the basis of the theory of physical education and sports, which stood out in an independent scientific field. If physical culture is a means of increasing productivity and achieving a high level of social production, the latter, in turn, provides appropriate conditions (material and spiritual) for the development of physical education and sports. Physical culture and sports, which until recently were only consumers of high technology, now themselves became their suppliers for many industries.

The modern focus on the creative assimilation of physical culture by the future specialist requires an orderly system of effectiveness on his intellectual, emotional, volitional and practical activities. This allows us to talk about physical education as an important way of forming a personality, citizen and future specialist, purposeful pedagogical process of involving student youth in the values of national physical culture. The purpose of physical education in higher education - the formation of physical culture of 
personality, creation conditions for general and professional training of students and increase on this basis of intellectual, creative and cultural wealth of the state. Achieving this goal involves the formation of the necessary motivational core of physical education and self-education, systematic physical culture and sports activities and development of physical abilities.

The student period, in fact, is the last opportunity to obtain a minimum of knowledge, skills and abilities in PE within the state education system. Later in life (in professional activities, life, family) caring for physical activity depends only on the acquired knowledge, skills and abilities.

Analysis of literature sources. Currently, much attention is paid to the scientific development of the introduction of increased physical activity of students in vocational training and improvement. However, the ways to increase the effectiveness of physical education of students in the literature available to us are covered in a rather contradictory way. Thus, in order to have a diverse impact of physical education on the body of students, increase motor density and physical activity, a number of authors propose to use the circular method of training [2]. At the same time, some authors prefer the complex development of physical qualities with an emphasis on up to $50 \%$ of the lesson time on speed and strength training. Some authors recommend to focus on educational activities aimed at the development of endurance quality [1]. However, some researchers [4] point to the need for focused, focused development in training sessions of motor qualities that lag behind. Also, a number of authors [3] considers the most effective form of physical education of university students such variant of employment in which specialization in this or that kind of sport with complex various physical training organically merges.

Presentation of the main material of the study. It is known that movements are the final expression of almost all processes occurring in the body. Unmet need for muscle activity has negative consequences for the functional state of the body and physical performance. Systematic physical exercises for a long period of time naturally lead to specific changes in the physical development of students. At the same time, the data of physical development studies become especially important when they are associated with indicators of the functional state of the organism, its efficiency and preparedness [1]. According to the concept of general adaptation syndrome, which occurs during stress, in the process of adaptation to muscle load in the body there are specific changes that increase the resistance to this agent. But, in addition, there are also nonspecific changes that are manifested in increasing its resistance to the influence of other different in nature agents. Each exercise, which differs from the other even by minor features of the structure of movements, is characterized by the specific impact on certain body functions. Currently, physical exercises are considered by many experts not only as a stimulator, but also as a regulator of the body's vital functions, which determine the possibility of their purposeful use in vocational training of students. muscular work, which is repeated many times, in the case of changing load. These changes in the body are considered as a cumulative training effect - a new qualitative feature of the body that arises as a result of summing up the urgent and delayed effects of a large number of individual training sessions. Therefore, for the possible detection it is proposed to conduct comprehensive research that provides pedagogical, medical and psychological evaluation criteria. The level of physical development is largely determined by a person's daily motor activity. The positive effect of exercise on human physical development and profound changes in the functional state of the body in persons engaged in physical culture and sports at different ages, marked by a number of authors [2] as the predominant indicators of dynamic life, compared with individuals In physical development, socio-economic factors that lead to the accelerated development of modern youth - acceleration - are still crucial. Therefore, a unified methodology of anthropometric research is used to study physical development. Vital capacity of the lungs is a standard indicator of the potential of the respiratory system in providing the body with oxygen. The highest value is observed in individuals who train for endurance and have the highest cardiorespiratory performance.

In today's world, the state of health of the population is considered an indicator of the level of development of civilized society. Physical education occupies a special place in human life and formation and is the main means of organizing motor activity, which from birth determines the basis of its socio-biological existence and development [4]. Physical education is the only academic discipline in higher education institutions aimed at attracting students to a healthy lifestyle, the formation of general and professional culture of the modern specialist, improving the physical and psychophysical condition of students [81]. Physical education of student youth is a holistic specialized process in which physical development is combined with mental education and upbringing, the purpose of which is to meet the needs of both the individual and society as a whole in the formation of a fully developed person, highly qualified specialist capable of successful professional activity [3]. The importance of physical activity is especially growing in modern conditions of society, when due to a sharp increase in the complexity of the educational process in general secondary education, the introduction of a multilevel education system in higher education, as well as mass computerization decreases physical activity of children, adolescents and young people. age, especially students of higher education institutions.

According to research, students' health can be managed by organizing and implementing impacts that are aimed at maintaining and strengthening primarily physical health. Characterizing the essence of the concept of "physical health", most authors understand it as the level of physical condition of the body, which is based on physical fitness, optimal functional state of the cardiovascular system as a universal indicator of adaptive capacity of the whole organism [5].

The problem of physical training is one of the most important at the initial stage of physical education and sports in higher education. It is closely connected with strengthening and preservation of health of students, formation of a physique, development and perfection of physical qualities which level of development characterizes motor function and is defined not only by physical, but also mental possibilities of an organism. At this age, exercise is most effective due to their effect on the body of young people. However, the results of entrance examinations for freshmen in the country's universities indicate their low physical fitness. Educational classes in the Free Economic Zone are conducted in accordance with the standard program, twice a week for two hours and have a positive effect on the physical fitness of students only under conditions of high intensity of physical activity and motor density of classes. Therefore, one of the conditions for successful work on physical education of students is skillful planning of educational material [2]. Solving educational problems related to the formation of technical skills to perform complex physical exercises recommended by the state program requires additional time. As a result, the motor density of the lesson decreases, the physiological load on the body of students, the time for physical training of students is significantly reduced. Some authors believe 
that a fairly high load can be achieved in lessons on the study of movement techniques.

Properly organized and individually dosed motor activity has a positive effect on the physical condition of students, in particular, expands the functional and adaptive capabilities of the cardiovascular, respiratory and other systems, improves redox processes, also increases the total lung capacity, is physiologically appropriate development of the capillary system, helps to increase the overall adaptability of the organism to adverse environmental factors [7].

It is recommended to assess the functional state of the body from a physiological standpoint. The impact of physical activity on the body has recently been assessed mainly by assessing physical performance. There are physiological and ergometric indicators that reflect the nature and degree of adaptation of the body to this load, as well as the amount of work performed during motor testing, which are considered to be the primary criteria for physical performance - the body's ability to maximize maximum consumption. At muscular loading, reaction to loading and speed of the recovery period upon termination of work. Objectively to estimate physical working capacity of a human body it is possible, studying functional level of its cardiovascular system.

Systemic response of the body in response to adequate physical activity contributes to its impact on structural and functional adjustment, which is characterized by the appearance of a number of physiological effects. Among them: increase of nonspecific resistance, expansion of compensatory and protective-adaptive possibilities, economization of physiological functions at rest and at the dosed physical activity [2]. According to rational physical activities influence also a functional condition of regulatory systems - nervous, nervous. In people who are engaged in health-improving forms of exercise, increases mobility and increases the balance of nervous processes, improves the functionality of the thyroid gland and adrenal cortex [57]. In modern learning, the intensity of mental work increases sharply, which also leads to reduced motor activity. as a result, there is psycho-emotional stress. This leads to even greater deterioration of health, psychophysiological status of students, complicates interpersonal relationships. A sharp decrease in the number of signals coming from the muscles to the central nervous system, negatively affects its activities and leads to reduced mental performance. There are also changes in the endocrine system, which contributes to rapid fatigue, emotional instability, deterioration of the process of cognitive activity, etc. [8]

Conclusions. Based on these features, researchers define motor activity as the sum of all movements due to the nature of work and rest, lifestyle, physical culture and sports, andimprovement of human biosocial nature by means of physical culture. Purposeful motor activity, which serves as a natural and socially determined need of the organism and personality in the maintenance and provision of onto and socio-genesis, active understanding and implementation of the subject of social significance, individual activities for physical self-improvement.

Sports training, associated with long-term cyclic work, contributes to the development of MSCs. During such work, oxygen consumption is approximately $78,2 \%$ of the MSC. In the case of training of short-term cyclic nature, as well as acyclic nature and situational types of muscular activity, the MSC is less. Aerobic capacity is limited by the speed of oxygen supply to the working muscles and depends more on the oxygen transport system formed by the circulatory and respiratory organs.

The value of MSCs is affected by systolic volume and wave volume of blood. The body's aerobic capacity reaches its greatest values by the age of 20-21 and is the biological basis of endurance. Indicators for studying the state of working capacity of individuals can serve as a criterion for assessing. In order to increase the level of physical fitness of students, according to some authors, it is advisable to take up to $75 \%$ of the lesson time for physical training, most of which are exercises for endurance.

This helps to improve the functional state of the cardiovascular and respiratory systems. This achieves the optimal level of coordination with motor function.

References
1. Bubley T. (2016) Features of planning and organization of physical education lessons for students with impaired health: status and prospects // Scientific Journal. Series 15. "Scientific and pedagogical problems of physical culture (physical culture and sports)". Issue 3K 2 (71) 16. K .: Published by NPU named after M. Drahomanov. 53-55 p.

2. Furmanov AG Health-improving physical culture: A textbook for university students / A.G. Furma-nov, M.B. Yusma. Minsk: Theseus, 2003. $528 \mathrm{p}$.

3. Griban, G., Tymoshenko, O., Arefiev, V., Sushchenko, L., Domina, Zh., Malechko, T., Zhuravlov, I., Tkachenko, P., Baldetskiy, A., Prontenko, K. (2020). The role of physical education in improving the health status of students of special medical groups. Wiadomości Lekarskie, 73 (3), 534-540. doi: 10.36740/WLek202003125.

4. Kholodov Zh.K., Kuznetsov VS Theory and methods of physical education and sports: textbook. allowance for students. higher textbook routine. 2nd ed. ispr. and ext. Moscow: Publishing Center "Academy

5. Physical education of students: [course of lectures] / for general. ed. RRSirenko. Lviv: Ivan Franko Lviv National University, 2011. $251 \mathrm{p}$.

6. Prysyazhnyuk SI Changes in the biological age of first-year students depending on the amount of physical activity. Theory and practice of physical education. 2006. No 1-2. Pp. 299-305

7. Shaposhnikova, I., Korsun, S., Arefieva, L., Kostikova, O., Serhiienko, V., Korol, S., Riabchenko, V. (2021). Analysis of students' somatic health and emotional state during sports games classes. Wiadomości Lekarskie, 74 (3 p.II), 608-612. doi: 10.36740/WLek202103208.

8. Tymoshenko, O., Arefiev, V., Domina, Zh., Malechko, T., Bondar, T., Tymchyk, M., Pliushchakova, O., Riabchenko, V., Griban, G., \& Prontenko, K. (2021). Exercise machines in speed and coordination development among students playing basketball. International Journal of Human Movement and Sports Sciences, 9(2), 347-355. doi: 10.13189/saj.2021.090224. 